\title{
Paratesticular Schwannoma
}

National Cancer Institute

\section{Source}

National Cancer Institute. Paratesticular Schwannoma. NCI Thesaurus. Code C162502.

A schwannoma that arises from the paratesticular region. 